\title{
A Step toward Social Transformation and Economic Emenciaption of Dalit in India
}

\author{
Uttam Kumar Sikder \\ Assistant Professor (Stage 2), Department of Economics and Politics, Visva- Bharati, Santiniketan-731235, \\ India
}

\begin{abstract}
The Indian society is guiding by the 'Manusmriti' written by Manu-the grate philosher in India, before thousands years which is called as 'Manuvadi-Samaj Vyavasta' based on socio-economic discrimination and exploitation by traditional caste system. Baba Saheb Dr.B.R Ambedkar has been trying to destroy it in his whole life and after 28 years of his death his follower Manyawar Kanshi Ram ji formed the Bahujan Samaj Party (BSP) in 1984 to make a 'Samatamulak Samaj Vayavastha' (An Egalitarian Society) in India. Now a day Behine Kumari Mayawati Ji, the only political heir of Kanshi Ram Ji and the present Chief Minister of the state of Uttar Pradesh in India is devoting her mission to create a social order based on equality by changing present inequitable social system where the interest of 'Sarva-Samaj' i.e. all sections of society are safeguarded. This is the main theme of this paper.
\end{abstract}

\section{Introduction}

The Indian society based on the traditional exploitative philosophy of of 'Chaturvarna' had led to an unequal socio-economic power structure. The evils of caste based society under the guiding principal of 'Manusmriti' written by Manu before thousands years have resulted in a economics and political decision making process over the years which mis-represent the social and economic interest of vast section of population. It can be argued that the notion of 'nationalism' as propounded by the 'Indian National Congress' prior to independence contributed negatively and paradoxically to sub nationalism and socio-economic retardation of the 'Bahujan Samaj' i.e. Scheduled Castes(SCs), Scheduled Tribes (STs), Other Backward Classes (OBCs) and Religious minorities. The members of this very significant part of our society are still languishing under the exploitative impact of a political framework which has an apparent bias in favour of the upper strata of society. In spite of the implicit provisions made for backward classes under Article-340 of the Indian Constitution, the fact is that only $1.2 \%$ of the total rural populations of the SC in the age category of 20 and above are Graduate. Similarly, just $1.1 \%$ of the ST populations in rural India are Graduate. This figure of the total Hindu OBC populations $2.1 \%$, while that for Muslims is just $1.3 \%$. Hence there seems to be a comprehensive class of deprive populations which includes not only conventionally perceived 'Dalits' i.e. (SCsSTs) but a 'Bahujan Samaj' which comprises SCs, STs, OBCs and Religious Minorities.

The idea of 'Bahujan Samaj Party's is a revolutionary one and widely inclusive that has led to a new socio-political order in recent years (since 1984). Any understanding of the nature of socio-economic deprivation of the oppressed is closely linked with the dramatic changes that have taken place in many part of the country. This has a far reaching implication for the dynamics of Indian polity. In my paper I will attempt to understand the new political structure which is emerging in this back ground with special emphasis on the scenario of state of Uttar Pradesh (U.P.) in India.

\section{Political Transformation in Uttar Pradesh and Socio-Economic Development Path under the Principle of "Sarvajan Hetai and Sarvajan Sukhai"}

The establishment of the Bahujan Samaj party (BSP) in Indian polity is based on the guiding economic philosophy of social justice and equity. These closely resembles with the notion of inclusive growth which intern implies equal sharing of benefits in the process of development by all section of the society. This philosophy is highly inspired by the notion of 'Sarvajan Hitai and Sarvajan Sukhai i.e. welfare for all and happiness for all of the Buddhist origin and advocated widely by Baba Saheb Dr. B.R. Ambedkar - The chief architect of Indian constitution.

Manyawar Kanshi Ram Ji was the founder of Bahujan Samaj Party (BSP) adopting a scientific outlook he had taken a significant step of far reaching consequences. Kanshi Ram Ji was of the view that the movement of "self respect and dignity" of the Bahujan Samaj should not be retarded due to the vacuum of leadership anymore. He had taken the lesson from the mistake of the past history of the movement after the death of Baba Saheb Dr. Ambedkar on $6^{\text {th }}$ December 1956. Kanshi Ram Ji followed the foot prints of the Saints, Gurus and Great men born in Bahujan Samaj at different times and drew inspiration from them, especially from father of 
the Indian Social Revolution Mahatma Jyotiba Phule, Father of Reservation Chhatrapati Shahuji Maharaj, Social revolutionist Narayana Guru, and Messiah of Humanity Baba Saheb Dr. Ambedkar, for full filling his dream of establishing a society where every one is equal i.e. "Samtamulak Samaj Vyavastha" i.e. Egalitarian society through "Social Transformation" in India. For this purpose on $6^{\text {th }}$ December 1978, he constitutes "BAMCEF" (Backward [SCs, STs, OBCs] And Minority Communities Employees Federation), D-S4 (Dalit Shoshit Samaj Sanghrash Samiti) on $6^{\text {th }}$ December 1981, and finally political outfit called BSP (Bahujan Samaj Party) on $14^{\text {th }}$ April, 1984 and through these three organizations he started working in that direction in a very scientific and systematic manner.

Today, Bahujan Samaj and Sarva Samaj i.e. all Sections of the society too feels as a mater of great happiness that for carrying and completing the progress of the Caravan of Kanshi Ram Ji. However, the leadership of Sarva Samaj has been eventually assumed by Kumari Maya Wati - The present chief Minister of U.P. She has emerged as the epitome and Pillar of Social transformation in order to establish a 'Samata Mulak Samaj'. The principles and policies of the BSP have been clearly highlighted on by Kumari Maya Wati after she assumes the position of the National President of BSP on $18^{\text {th }}$ September, 2003.

The principles and ideologies of the BSP are not against nay caste or creed; rather BSP wants to establish a casteless "Samtamulak Samaj Vyavastha" (a society based on humanity and equality) by briuging together various groups of people through social brotherhood who were separated on the basis of caste and creed. And by following these principles alone the social order with inequalities and discriminations can be uprooted completely from this country. But Bahujan Samaj, which consists of Scheduled Castes, Scheduled Tribes, Other Backward Classes and Religious Minorities like Sikhs, Muslims, Christians, Parsis and Buddhaists, can not by themselves change the social order and establish a Samtamulak Samaj. For achieving this big and high objective they will also have to take along with them the people of Savarn Samaj (Upper Caste) by getting them together on the basis of brotherhood and only then Samtamulak Samaj Vayavastha as per the thinking of Baba Saheb Dr. Ambedkar can be established in the true sense of the term and with this only their poverty, unemployment and other fundamental problems can be solved. This task cannot be accomplished by the Indian National Congress, BJP or other opposition parties, which have always gained power at the center as well as various states on the basis of 'Dividing the society in the name of caste and creed with the help of capitalists' by ensuring defeat of the people having votes by misusing money power.

As far as the programmers and policies of the BSP Government in Uttar Pradesh are concerned, every policy is formulated keeping in mind the government enshrined under the theme of "Sarvjan Hitai and Sarvjan Sukhai". The ideology of social brotherhood as well as equality is clearly reflected in them.

The state Government formed by Bahujan Samaj Party has paid more attention, on priority basis, to the upliftment of Scheduled Castes/Scheduled Tribes, other Backward Class and Religious Minorities in all spheres in the state of Uttar Pradesh and for this purpose in the year 1995 itself when the first government of Bahujan Samaj Party was formed, separate government welfare departments were constituted in U.P. for the first time in this country.

The Bahujan Samaj Party Government has made a positive beginning in the direction of initiating a New Positive Reservation Policy in the interest of Upper Castes, Scheduled Castes, Scheduled Tribes and Other Backward Classes. As is well known to everyone that though due to the untiring efforts of Baba Sahab Dr. Bhimrao Ambedkar, the facility of reservation has been provided under the Constitution of India to the Scheduled Castes, Scheduled Tribes and Other Backward Classes in Government Services etc. but because of anti reservation mentality of the Congress, BJP and their supporting parties betraying constitution the Full Benefit of Reservation is not yet being made available to these classes. The quota of reservation has never been filled in Government Services at all levels. Apart from this, the Facility of Reservation has not yet been provided to them in all the other areas where there is an urgent and acute need for providing reservation.

But in Uttar Pradesh the Bahujan Samaj Party (BSP) Government has taken several significant and historical decisions in this regard for the first time in the country. For the last several years, several Government Departments and Organizations are being given to private sectors on a large scale on the pretext of their sickness and weak status but without providing the continuance of Facility of Reservation at any level in these private sectors. If this process continues; if the works of Government Departments and Organizations are gradually given to the private sectors then a day will come when the job reservation will be lost, and the practice of Reservation will be completely vanished from the whole country.

However, the BSP Government in Uttar Pradesh has taken up this issue in all seriousness and also written to the Central Government making a request that before giving any Government Department or Organization to Private Sector same percentage of quota should be ensured in the said private sector for those classes who were getting this benefit while working there. But unfortunately neither the Central Government nor any other State Government has accepted this suggestion. It is only the Government of Bahujan Samaj Party in Uttar Pradesh which has taken initiative in implementing a new policy of reservation, which is as follows: 
(1) Public-Private-Partnership (PPP) is a significant and integral part of the realistic and pragmatic economic policy of the Government initiative of taking everyone along (all inclusive). The State Government will have a maximum partnership of $49 \%$ and minimum of $11 \%$ in all the schemes/projects/industries etc. to be established in any field with the partnership of the State Government so that the maximum benefit of the same may be attained and the same arrangement of reservation in service will be maintained in the Industries developed on Pubic-Private-Partnership model as is available in the employment of the State Government. Hence, in the industries established and developed on PPP model reservation of $21 \%$ of the total employment will be provided to the Scheduled Castes, $2 \%$ will be provide to the Scheduled Tribes and $27 \%$ reservation will be available to the Other Backward Classes. Along with this the welfare of the employees will also be ensured in the projects/industries established under the PPP model.

(2) Not only this the Government of BSP has also ensured that if the works which were being performed by various Government Departments, Corporations, Authorities, Boards and any other SemiGovernment Organizations through their own employees, are now conducted on the basis of outsourcing, then even in such agreements also provision of providing $21 \%$ reservation for persons belonging to Scheduled Castes, 2\% for persons belonging to Scheduled Tribes and 27\% for the persons belonging to the Other Backward Classes will be made in the total employment.

(3) Repeatedly to The Government of India has been requested that the posts which are lying Vacant in the Central Government services under the Reservation Policy should be filled immediately and in the Private Sector also similar reservation policy as enforced in UP by the BSP Government should be implemented and it should also be included in the IX Schedule of the Indian Constitution so that the same could be not be disturbed anymore.

(4) Along with these, such persons belonging to Schedule Cates, who got converted to become Dalit Christians or Dalit Muslims, should also be given the benefit of reservation by adding the reservation percentage proportionately thereby keeping the present reservation percentage for Scheduled Cates intact and for this the appropriate amendment should be made in the Indian Constitution for relaxing the maximum limit of $50 \%$ quota being emphasized by Hon'ble Supreme Court and such amendment should thereafter be placed in the IXth Schedule of the India Constitution so that this arrangement is made permanent.

(5) The BSP government on the basis of the Policy of "Sarvajan Hitai, Sarvajan Sukhai" has demanded from the Government of India that necessary amendment should be made in the Constitution, to provide the Benefit of Reservation, even to the persons belonging to Upper Castes, living below the poverty line. The Bahujan Samaj Party is giving an assurance to these people belonging to the upper caste that the day Bahujan Samaj Party Government is formed at the Centre, like in Uttar Pradesh, the facility of reservation will be provided to them without it being asked for. Besides the BSP government will make a meaningful effort to eradicate poverty and unemployment of these sections of the society.

(6) As far as the question of implementing Scheduled Castes and Scheduled Tribes (Prevention of atrocities) Act, 1989 is concerned. This is a central act made by the Government of India and no State Government can either make any amendment to it or abolish it. The BSP Government is strictly implementing the same in letter and spirit.

Not only this, the BSP, along with Bahujan Samaj, has also given postion of eminence in the Party Organization to the persons belonging to savarn Samaj, keeping in view their sacrifice, commitment and devotion towards the Party and its policies.

The communities belonging to Savarn Samaj were also given equal participation in the Lok Sabha and Vidhan Sabha elections depending upon their preparations and they have also been inducted in the cabinet in a sizable number.

Hence, BSP has proved beyond doubt that it is the only party in the Country which can give an ultimate Government committed to the welfare of the Sarva Samaj to the benefit of the Nation and which can help establish a Samtamulak Samaj Vayavastha by uniting the Sarva Samaj through brotherhood. The performance of the BSP government in Utter Pradesh, which is population wise the biggest sate of India is a living example of this new phenomenon.

Since independence the Indian National Congress, BJP and other opposition parties associated with them have ruled at the Centre and in the States, but they made no sincere efforts to ameliorate the economic and social backwardness of Bahujan Samaj or of the poor and unemployed belonging to Savarn Samaj (upper castes). Similarly, the condition of "Farmers', 'Laborers'. 'Employees'. "Advocates', "Small Businessmen' and other sections of the society is far form satisfactory. Therefore all these sections of the society are facing hardship and harassment all over the Country. 
Consequently, a very large chunk of our population has been the victim of neglect of the Government during the past more than 64 years after independence and their lives have been pathetic and painful even after more than 64 long years of independence and during this period, three consecutive new generations of this Country had emerged to face this painful situation.

But who is responsible for this messy condition. Prima facie, the main reason for social, educational and economic backwardness of this huge population of Bahujan Samaj and poor amongst the upper castes is the wrong economic policies pursued especially by the Indian National Congress and the BJP and their supporting parties for they are not honest in their intentions and policy towards the true welfare of the masses. However, today the BSP is the only option and a party committed through its policy and programmers to remove the Social, Economic and Educational backwardness from the society taking every section in its fold.

Like the Indian National Congress and the BJP, the other opposition parties also have the same attitude which means that though these parties' existence and entity are separate but they share the same particular type of obnoxious faulty ideology and thinking. All of them have the same God-fathers who are very big Capitalists. These political parties and big capitalists have always been complimentary to each other. Both of them feel proud in serving each other's interest. Their concern towards the problems of general public is artificial and mock. They shed only crocodile tears for poor, labourers, farmers and people belonging to middle income group of the Sarva Samaj. This is the reason why ominous phenomenon of hunger, unemployment and illiteracy still exists like a demon in the country even today. These evils do not come to an end because the economic policy of the Country is dominated by wishes of capitalists and the Congress, BJP and their allied parties have no true intention or real policies to eliminate the hawkish problems being faced by the huge population of poor and unemployed belonging to all sections of the society.

In nutshell, it is very much evident that due to the wrong economic policies of the Congress at Centre and previous Government of NDA headed by the BJP, in the last 20-25 years the rich have become richer and poor have become poorer, this State of Affairs is very unfortunate. It is due to wrong policies of the present Congress-led UPA Government at the Centre which boasts of approximately more than $8 \%$ economic growth but in real terms the conditions of laborers and middle class persons has worsened.

From the above account of major aspects of BSP's socio-economic and political agenda, it becomes self evident that the BSP is gradually emerging as the central force to defend the downtrodden and oppressed. The Marxist Party line involves the revolutionary role of the working class to abolish the class conflict in a class based exploitative society. In the Indian context of a caste based social hierarchy, the BSP seems to be a potentially dynamic force to abolish the exploitation based on caste differentiation. However in keeping with the sprite of social democracy, it aims at a social revolution by taking all sections of the society together. Hence in building up an egalitarian society BSP calls for a partnership of all forces which stand united to fight out discrimination at different levels of the prevailing socio-economic and political scenario.

\section{Conclusion}

Our exposition on the emerging socio economic and political dynamics in India in the light of a Bahujan Samaj orented philosophy reveals a number of significant observations. There is little dought about the fact that in recent years the 'Dalit led' qualision has emerged as an effective alternative to the existing political framework which survives on a more or less monopolized social segmentation involving upper caste people. This framework is broadly guided by reactionary and Manuvadi ideological order which stands in a big way as an obstacle to socio-economic upliftment of the vast Bhaujan Samaj comprising the weaker section not only from the class of dalits and other minorities but also from the class of relatively poorer upper social Strata. The victory of the Maya Wati Government in UP in the last Vidhan Sabha election in 2007 clearly points to a victory of a comprehensive alliance of all socio-economic groups in initiating a new era of development.

The basic philosophy of BSP as a political organization clearly indicates development based of self respect and dignity inspired by the egalitarian principles of social progress advocated long before by Dr. Ambedkar. My critcal outline on the policy of 'Samatamulak Samaj Vavasta' and 'Sarvajan hatai and Sarvajan Sukhi" helps us to derive the proposition that the welfare of Sarva Samaj in ensured only with BSP. Thus the principles of BSP lead ultimately to the principles of determining a social welfare function which promises and end to caste conflict. This is very similar to the idea of removing 'socio-economic dualism' through a policy of development based on a participation cutting across all weaker sections.

Finally, the BSP has defeated in 2012's Assembly election in UP after completing five years rule by absolute majority due to the fact that the social engineering policy of "sarva samaj" has been failed. The base vote of BSP, namely SC's \&ST's vote bank is more or less same but only $3 \%$ previous vote was transferred by the rest of the society in favor of SP indicating the fact that the popularity of the supreme of BSP has declined .Also the anti incumbency factor is responsible for that defeat of BSP. Now we would be observer the results of the coming 16-th parliamentary election of India. 


\section{Acknowledgement:}

I am indebted to my father Bodhisattva Makhan Lal Sikder and also my mother Smt. Labanya Prova Sikder for guiding me in all walks of life and giving me freedom and courage to be myself.

\section{References}

[1]. Chaudhury, 2004, "The "Creamy Layer"” Political Economy of Reservations, EPW, Vol. 15-21,pp. 1989-1991.

[2]. Dr. B.R. Ambedkar, "Annihilation of Caste", Writings and Speech, Volume-1, Education Department, Maharashtra Government, pp.47.

[3]. Kumar V., 2004, Understanding of Dalit Diaspara, EPW, VOL. 1, Jan 3-9, pp.114-116.

[4]. Kumar V., 2001 A Blow for Dalit Dignity and Pride. The Pioneer, September 25, New Delhi.

[5]. Venkitesh Ramakrishnan, "Winning Formula", Front Line, June 1, 2007

[6]. Zoya Hasan, "What next"? , Front Line, June 1, 2007

[7]. Praful Bidwai, "Creating History", Front Line, June 1, 2007

[8]. "Parliament House, the Temple of Power at the Centre", Bahujan Samaj Party, 12, Gurudwara Rakab Ganj Road, New Delhi.

[9]. "Welfare of Sarva Samaj is Secured - only with BSP", BSP central Unit, and 16-Gurudwara Rakabganj Road, New Delhi

[10]. Uttar Pradesh: One Year of Development and Progress, Information and Public Relation Department, U.P. Lacknow

[11]. Government of India, Constitution of India 